\title{
The Countervailing Powers of Hospitals' Choice During the During the 1918 Influenza Epidemic in Chicago
}

\author{
Blair Gifford \\ University of Colorado Denver
}

\begin{abstract}
Voluntary hospitals were becoming medical science workshops for physicians and paying patients in the 1910s, leaving contagious patients admissions for government hospitals. However, they had to weigh community needs versus medical science care during the 1918 influenza epidemic. Using extensive archival evidence from multiple historic sources, it is shown that voluntary hospitals in the Chicago area responded quickly to the influenza epidemic that appeared in September 1918 and quickly surged to a high number of contagious patients. The active response by voluntary hospitals reinforced the original community service orientation that led to the quick proliferation of hospitals at the turn of the $20^{\text {th }}$ century and crystallized what it meant to be a voluntary hospital.
\end{abstract}

Keywords: influenza pandemic, hospitals and covid, community institutions

\section{INTRODUCTION}

Hospitals were just starting to gain the public's trust for medical efficacy at the turn of the nineteenth century. With support from poor and wealthy alike, hospitals started to consider how they might combine a charitable tradition with the medical advances that brought top doctors and paying patients to their doors. It was during this early period of increasing appreciation and use of hospitals that the 1918 influenza epidemic suddenly struck and brought an overwhelming surge of patients to be cared for.

The number of flu cases began to increase and become noticed in early September. By late September, it was clear that an epidemic was at hand. Public health officials scrambled to find ways to lessen contagion in public spaces. At its height, during an eight-week period from late September until mid-November, there were two thousand plus new cases of influenza and pneumonia each day. These cases resulted in over five hundred deaths a day in Chicago at the peak of the epidemic.

Using a unique set of historical data that has been collected on the complete population of Chicago's hospitals, this research will provide a picture of how hospital types differed in their approach to influenza crisis. At the moment, buildings had to be repurposed and new temporary facilities were built and staffed. However, the crisis had a longer-term effect on hospitals, too. Hospitals were forced to re-consider how they would go forward with their community mission. In effect, the 1918 epidemic crystallized what it meant to be a voluntary, private hospital and how such hospitals would differ from government hospitals in coming years.

To appreciate the shifting institutional orientation of hospitals, this paper will first provide a brief social-historical context of the burgeoning hospital industry in Chicago at the turn of the nineteenth century. This history isn't just about hospitals. It is also about immigration and community change; how various 
religions went about providing a health safety net for their members; and, how doctors influenced the development of hospitals into their professional workshop. Given these various influences, the paper will describe how hospitals, during a moment of crisis, responded to community need, but also redefined their institutional purpose.

\section{URBANIZATION, IMMIGRATION AND THE GROWTH OF HOSPITALS}

The first census of hospitals in the U.S. was done in 1873. It listed only 178 hospitals nationwide, and of these, most were long-term care institutions, many of which were state and private asylums for the insane (Toner, 1873). However, hospitals were just beginning to move to the forefront with the ongoing urbanization and immigration of the period. From 1870 to 1890 the population of Chicago quadrupled from 300,000 to 1.1 million, and by $1890,78 \%$ of the population were foreign born or children of foreign born. ${ }^{1}$ In response, smaller charitable hospitals were built throughout Chicago's communities to accommodate the special needs of the various religious and ethnic populations. A hospital could be a place of comfort to various beliefs, customs, languages, and races, as well as a site of medical care.

Many working-class Chicagoans endured economic uncertainty and hardship. Unemployment always seemed to be lurking around the next corner, and family illness or an unexpected death could shatter an already fragile existence. Foreign born populations shied away from most public charity because there was a deep distrust of public assistance. In the "old country" there was no such thing as public relief, and they did not expect it or look for it in America (Cohen). Unlike other forms of charity, such as housing and food stuffs, medical charity could easily be linked to the burgeoning world of science, the modernism that awed many immigrants into coming to America in the first place. Other forms of charity were still too close to home and could be found with the community setting.

But medical care was different. It represented a new, and exciting world, and, as such, accepting medical charity was less of a humbling experience and more of a new society that lay beyond the confines of family and community. The science of charity was an attempt to distinguish among those who were in a temporary state of poverty or made dependent by diseases and disability from those who took advantage of charity and would arguably become dependent on charity. Charity hospital patients, although poor and often immigrants, were perceived to be morally redeemable and medically curable. While patients at the large public hospitals were generally terminal or not seen to be "worthy" due to diseases like alcoholism, insanity and venereal diseases.

\section{HOSPITALS: THE NEW MEDICAL WORKSHOP}

The introduction of aseptic medicine, anesthesia, and $\mathrm{x}$ ray technologies in the $1890 \mathrm{~s}$ and clinical labs and early 1900s greatly enhanced the capabilities of hospital-based care. Physicians took advantage of these medical science advances and began to open small, proprietary hospitals, usually with a strong surgical orientation. Ethnic, foreign born physicians, who had been discriminately excluded from other hospital staffs, were often the enterprising forces behind these hospitals. A variety of health institutions developed. Hospitals were often started and owned by medical schools, religious groups, individual doctors and even companies such as railroads. Cities and factories provided a population base to support new health care institutions, and the establishment of a hospital became the goal of every civic-minded community (Starr, Stevens, Vogel, Rosenberg).

In view of the government's expanding role in providing medical care, the availability of free care in many hospitals and dispensaries, and competition from irregular physicians (Numbers, 1978), American physicians grew increasingly concerned about their financial status. Medical journals across the country published editorials bemoaning the low income of doctors, which they sometimes estimated to be as low as $\$ 500$ or $\$ 750$ a year, scarcely more than that earned by manual laborers (Van Sickle, 1916: 292). In 1913, the Judicial Council of the American Medical Association reported "that hardly more than 10 percent of the physicians in the United States are able to earn a comfortable income" (Report of the Judicial Council, 
1913: 1998.) However, further evidence indicates that the medical profession was probably not as badly off as it imagined (Numbers, 1978: 9).

As more and more workers, unable to afford private physicians, but otherwise self -sufficient, turned to charitable inpatient care and dispensaries, ${ }^{2}$ the medical profession grew increasingly suspicious that hospitals and dispensaries were treating for free patients fully capable of paying. In 1908, Dr. Clarence Leigh of the North Shore Branch of the Chicago Medical Society cited statistics which suggested that \$7 million of non-reimbursed medical care was provided annually by three thousand physician, which equates to about $\$ 2,500$ of charitable work per year by physicians in Chicago (Chicago Medical Society, Nov. 28, 1908). However, it appears that the $\$ 7$ million figure is purely a physician-derived statistic reflecting the "value" of treatment. For example, Chicago's Bureau of Charities spent \$2.5 million in 1907 for medical care across all hospital types in Chicago.

Medical practitioners also became increasingly upset with the lack of regulation and standards in the industry. Anybody, it seemed, could get a medical degree and practice at hospitals which ranged radically in terms of quality care. To protect itself, the medical profession was instrumental in working with the Carnegie Foundation to research the condition of medical schools in the U.S. The resulting Flexner Report (1910 led to closure of almost half of the medical schools in the U.S. and the standardization of medical education in the others. Furthermore, the profession led the fight to regulate hospital care. In 1917, the American College of Surgeons set standards of accreditation for hospitals that are still in use today, albeit in radically different terms. These actions and others indicated that the medical professional, itself aglow in the light of a medical science ethos, was beginning to redefine medical care away from a charitable orientation.

\section{The 1918 Influenza Epidemic in Chicago}

The exceptional virulence of the influenza strain of 1918 first became apparent during August outbreaks in Africa, Europe, and North America. No other modern strain of influenza led so frequently to deadly pneumonia. Unlike the 2020 influenza pandemic, younger adults were very susceptible and general good health seemed to provide no defense against the virus in 1918. Further, the continued wartime mobilization of soldiers and civilians created optimal conditions for the spread of the highly contagious virus. Global fatalities exceed twenty million and may have approached forty million. Influenza and pneumonia deaths in excess of half a million happened in the United States.

In Chicago, city health officials became alarmed about a marked rise in deaths in the suburbs to the north. On September $21^{\text {st }}$, Chicago had its first recorded death due to the acute respiratory problems that the epidemic presented. By September $30^{\text {th }}$ there were at least 260 known cases of the influenza virus. This sudden surge led the Health Commission, Dr. John Robertson, to order patient isolation at the large and renowned Cook County Hospital. Military officers, at nearby Great Lakes Naval Training Station, instituted isolation and quarantine controls for those who became sick. All 50,000 sailors on hand were to be given daily nose and throat sprays. Overall, 1000 men were soon put in isolation, another 4,000 sailors were put under quarantine, and liberty leave was canceled for all. cite

On October $11^{\text {th }}$, the new and quickly formed Illinois Influenza Advisory Commission banned public dancing and public funerals. At this point, the spread of the flue had gone parabolic reaching upwards of 2,000 cases and 500 deaths a day from influenza and phenumonia. On October $15^{\text {th }}$, city leaders closed theaters and night schools. Churches and schools were left off the closure list, but clergy were asked to shorten services and students were beginning to not show up for classes. Mischievous students even took to sniffing pepper in order to induce a coughing or sneezing fit, knowing that the school health officer would send them home for a week. On October $16^{\text {th }}$, the Commissioner ordered that all non-essential public gatherings be banned and that social distancing be practiced. However, some exceptions like saloons and restaurants were made. How could they be? Not everyone had an icebox to keep food fresh or a kitchen in which to prepare it.

Doctors and nurses worked around the clock while citizens were trying to understand and cope with the crisis. Morris Fishbein, a prominent Chicago doctor who later became the editor of the Journal of the American Medical Association, wrote in his memoirs that most Chicago physicians visited some "sixty to 
ninety patients each day" at the height of the epidemic. However, they were generally unable to do much besides trying to make patients comfortable Cite. There was little that could be done. The front page of the Journal of the American Medical Association stated as much. "Unfortunately we as yet have no specific serum or other specific means for the cure of influenza, and no specific vaccine or vaccines for its prevention...the physician must not allow himself to be led into making more promises than the facts warrant (Oct 26, 1918)."

By late October, new case reports indicated that the epidemic might be on the decline. With danger seemingly passing, the Chicago Tribune newspaper started putting pressure on the health commissioner to loosen all restrictions. The editors sarcastically called the Commissioner "his highness" and "his eminence," and wrote: "outside of the fact that you mustn't cough, sneeze, expectorate, or osculate, mustn't smoke on street cars or elevated trains, can not visit sick friends and must continue to observe food and fuel regulations and keep up your installment payments on Liberty bonds, you can get up tomorrow and do as you please." At first, the Health Commissioner didn't budge from his strict and unprecedented position, but as cases dwindled he allowed all restrictions to subside on November 16.

Overall, more than fourteen thousand Chicagoans, in a city of almost 2.7 million, died of influenza or pneumonia between mid-September of 1918 and March of 1919. During that period, the weekly death rate leaped from 10.8 per thousand to 63 per thousand (i.e., one in 16 people) in late October 1918. During the peak period of the crisis - September 22 to November 16 - the Department of Health received reports of 37,921 influenza cases and 13,109 pneumonia cases. Of all these cases, there were about 8,500 deaths, an almost $17 \%$ rate of death for those who fell ill in an eight week period at the height of the epidemic. Officials acknowledged, however, that sickness was far more widespread than their statistics indicated, and that thousands of cases went unreported (Ruth, 1991).

With the main danger over by January 1919, the Health Commissioner turned his attention to correcting shortcomings in the health system. In particular, a need to fix the acute nurse shortage. The Commissioner recommended that the education needed to complete a degree for registered nurses be decreased from three to two years. Also, he recommended that a new cadre of nurses "practical nurses" be formed. This new cadre of nursing would need only six months of intensive training. Legislators quickly passed the bill for these changes, and in July, Chicago's Training School for Home and Public Health Nursing opened its doors. Nearly 800 women completed the inaugural curriculum, and 600 of these answered the call for volunteers when influenza returned, at a lower incidence rate, in 1920. Within 2 years of the start of the school, there were 3000 graduates. Accordingly, a second program of Practical Nurses was started in connection with the Municipal Tuberculosis Sanitarium to be available for future epidemics.

\section{The Development of Voluntary Hospitals}

In the early 1900s, private hospitals in the United States had begun to move away from a primary charitable orientation to become "voluntary." At the time, the use of voluntary to describe a hospital meant that it had developed a dual mission of charity and medical science. Voluntary hospitals didn't want to break away from their charitable, community-oriented past. However, they needed extra resources to maintain the continuance of their charitable mission. With the excitement of new medical capabilities, hospitals began to embrace a medical science orientation, too. Such an orientation was the new modernism of the day.

This new dual orientation allowed voluntary hospitals to maintain community support while increasing revenues. By attracting talented doctors, hospitals were able to gain an increasing number of paying patients especially shorter term medical and surgical patients. By keeping a charitable orientation, hospitals were able to gain donations from their communities of support and patients to afford the care of those who were less financially able, but worthy. ${ }^{3}$ Hospitals had clearly become needed community institutions. As such, the growth in the number of hospitals was exceptional. By 1910, there were almost five thousand husbands in the U.S., and the ration of hospital beds per person was equivalent to what it is today.

As Table 1 indicates, the large voluntary hospitals received almost two thirds of revenues for all hospitals in Chicago. Their revenues came from multiple sources including patient care, donations and other. Clearly, voluntary hospitals were continuing to compete for funds and paying patients, but for 
medical reputation as well. Government hospitals received appropriations from their various sources (i.e., Cook County, the U.S. government). Proprietary hospitals, which were smaller and typically founded by a physician, relied almost exclusively on patient care for revenues, while specialty hospitals - like maternity care, eye, ear and nose and child hospital facilities relied less on patient payments and more on donations and "other" for revenues.

A noteworthy outlier to the above trends is Cook County Hospital. In 1910, Cook County Hospital's accounted for almost a quarter of all hospital beds and its $\$ 642,000$ of expenses accounted for about a quarter of general care hospital expenses in Chicago (Cook County). As a governmental hospital, Cook County provided much charitable care, but it also was a hospital of great distinction for the medical care that it provided. Indeed, it was quite an honor to be a physician with admitting privileges at Cook County. Also, the hospital served as a primary source for residencies for recent medical college graduates.

\section{TABLE 1 \\ CHICAGO HOSPITALS' REVENUES PER BED BY HOSPITAL TYPE IN 1910}

\begin{tabular}{|c|c|c|c|c|c|c|c|}
\hline \multirow[b]{2}{*}{ Type (n) } & \multicolumn{7}{|c|}{ Source of Revenues (in '000s) } \\
\hline & Beds & $\begin{array}{c}\text { Total } \\
\text { Revenues }\end{array}$ & $\begin{array}{c}\text { Govt } \\
\text { Funds }\end{array}$ & Donate & $\begin{array}{c}\text { Patient } \\
\text { Care }\end{array}$ & Other & $\begin{array}{c}\text { Revenue/ } \\
\text { Bed }\end{array}$ \\
\hline Proprietary (12) & 538 & $\$ 271.2$ & $\$ 0$ & $\$ .7$ & $\$ 270.5$ & $\$ 0$ & $\$ 504.2$ \\
\hline Voluntary (29) & 4119 & $2,240.6$ & 0 & 218.2 & 1715.1 & 307.2 & 544.0 \\
\hline Specialty (7) & 261 & 188.6 & 3 & 71.2 & 49.2 & 65.2 & 722.6 \\
\hline Gov't (4) & 1721 & 689.0 & 689 & 0 & 0 & 0 & 400.3 \\
\hline Total (42) & 6639 & $\$ 3,389.4$ & $\$ 692$ & 290.1 & $2,034.8$ & $2,034.8$ & $\$ 544$ \\
\hline
\end{tabular}

Note: the category "other" is not defined or described in the survey.

Source: 1910 Benevolent Institutions Survey, Dept. of Commerce and Labor, Bureau of the Census. Washington: Government Printing Office, 1911.

\section{Voluntary Hospitals Move Away From Contagious Disease Patients}

A charismatic protestant religious leader of the time, with a large national following, was Dwight L. Moody of Chicago. Moody preached that unemployment and poverty were a judgement from God, but that individuals who worked hard to lift themselves up financially would be saved. This line of thought was a departure from traditional religious beliefs about how the poor were both necessary. Poverty brought humility and gratitude and provided the financially well off with an opportunity to practice charity and kindness (Rosner).

Moody's preaching about the "gospel of wealth" gained much support from industrial leaders in Chicago like Cyrus McCormick and George Armour, and it provided the religious and philosophical foundation to a growing science of charity that would had started to be enacted for admittance to voluntary hospitals in Chicago. Those who gained admittance as charity patients, although poor and often immigrants, were perceived to be morally redeemable and medically curable, which was in line with the new "gospel of wealth."

The charitable religious movement also led voluntary hospitals to distance themselves further from governmental hospitals. The increasing prominence of technology and the physicians who employed these impressive new tools expressed itself in another particularly tenacious way. In every city, private voluntary hospitals exercised their ability to select among an available patient population, avoiding chronic and contagious patients. As Henry Hurd, the superintendent of Johns Hopkins candidly argued in 1912: voluntary hospitals cannot receive these patients without detriment to the interests of their special patients." (President's Address, Hospital World 2 (1912).

Voluntary hospitals, presumably beholden to an institutional environment that favored worthy charity and medical science, had begun to act with an inwardly focus toward giving primacy for acute care, paying patients. Diagnosis and therapeutic capacity as well as an individual's social location had begun to 
determine hospital admission. Hospitals' commitment to the community had become a mere glance outward in comparison to the compulsion exerted by forces that shaped voluntary hospitals inward vision.

Voluntary hospitals had thus further defined their mission. They maintained a charitable mission, advanced a medical science orientation, but some voluntary hospitals were starting to move away from admitting chronic patients, including those with contagious diseases. Such patients would have to seek services at governmental hospitals. As a result, patients at public hospitals started to be seen as wards of the state and generally terminal. That is, they were not seen to be "worthy" due to "diseases" like alcoholism, insanity and contagious diseases like tuberculosis and sexually transmitted diseases such as syphilis and gonorrhea.

A 1904 survey by the US Government of Benevolent institutions like hospitals indicated that many voluntary hospitals in Chicago had moved away from admitting contagious diseases. In 1910, the Government repeated the survey and got the similar results. As Table 2 shows, almost two thirds of voluntary hospitals, including most of the prominent hospitals in Chicago, maintained a non-contagious admittance policy. There were some exceptions to the no contagious rule policy. It was a clearly a time of indecision for Voluntary hospitals about how to proceed. However, a line was drawn at Cook County Hospital. It had been acting much like a voluntary hospital, but when it came to admitting contagious patients, it needed to be true to its public and government orientation. Yet, it should be pointed out that since Cook County was almost always filled, they probably re-directed many contagious patients to nearby governmental contagious disease facilities.

\section{TABLE 2 CHICAGO HOSPITALS' WHICH DID NOT ACCEPT CONTAGIOUS PATIENTS BY HOSPITAL TYPE IN 1910}

Private (4 of 12) - Abraham Lincoln, Jefferson Park, Monroe St., So. Chicago
Voluntary (18 of 29) - Chicago Baptist, Chicago Homeopathic, Chicago Un
Willard, German, Henrotin, Mercy, Michael Reese, Norwegian Tabitha,
Presbyterian, Ravenswood, St. Elizabeth, St. Joseph, St. Luke's, St. Mary Nazar
Wesley Hospital (2820 beds total)
Specialty (1 of 7) -Children's Memorial (110 beds total)
Government (0 of 4) - all government hospitals accepted contagious patients

Source: 1910 Benevolent Institutions Survey, Dept. of Commerce and Labor, Bureau of the Census. Washington: Government Printing Office, 1911.

\section{Chicago's Hospitals in the 1910s}

Trying to determine how hospitals responded to an influenza epidemic over 100 years ago requires archival work, especially since many of the 1910 and 1920 hospitals in Chicago no longer exist. In the late 1980 and early 1990s, the lead author approached existing hospitals from the 1910 to 1920 study period to determine whether they have archive materials of use to this study. Historical information was collected from numerous hospitals in Chicago (St. Elizabeth, Presbyterian, Englewood, Michael Reese, Lutheran Deaconess, Cook County, Passavant, and German/Grant Hospitals). These hospitals represent a variety of hospital types and geographical areas in Chicago. Additionally, basic hospital data were collected from the Chicago Medical Society, Blue Book (bi-annually 1905 through 1953), the U.S. Bureau of the Census, Survey of Benevolent Institutions (1904 and 1910), the Annual Survey of Hospitals (American Hospital Association), Medicine in Chicago, 1850-1950 (Bonner, 1957), and the History of Medicine and Surgery: Physicians and Surgeons in Chicago (Chicago Medical Society, 1922). The author took considerable time gathering and comparing hospital data from the various sources. As a result, the hospital data that has been 
assembled for this research is quite a bit larger than any particular historical source, but is as complete as can be.

Chicago's hospitals in 1910 have been divided into four categories for this research: 1) Proprietary paying patients only, typically smaller and physician initiated, 2) Voluntary - hospitals that combine charity and paying patients, 3) Specialty - hospitals that provide a particular service such as maternity, psychiatric, children, eye, ear, nose and throat, 4) Government - these hospitals can be general, specialty and public health (contagious). Also, in determining whether a hospital was Voluntary much consideration was placed on the extent to which a hospital provided charity care or not. It was decided to use a $5 \%$ cut off level for charity patients. That is, those hospitals which provided $5 \%$ or more of charity care were labeled "voluntary," while those below 5\% were labeled "proprietary." Note that almost all Voluntary hospitals were well above the cut-off level in a range of 15 to 35 or even $50 \%$, while those categorized as Proprietary generally offered no charitable care at all.

Table 3 shows that total number of hospitals in Chicago increased from 80 to 97 (a $19.5 \%$ increase) during the 1910 to 1920 period. This is in line with the $23.6 \%$ of growth in Chicago's population during the period. However, just considering the total number of hospitals does note provide an understanding of the capacity of hospital. That is, bed size is a stronger measure for this. As shown, the total number of hospital beds increased tremendously from 8,283 beds in 1910 to 14,892 beds in 1920 (a -\% increase). Private hospitals capacity increased at a $45.7 \%$ rate and government hospitals increased at an outstanding rate of $192 \%$.

Voluntary hospitals only increased their capacity ( $24.8 \%$ increase in beds) in line with population growth in Chicago of the 1910s. This can be explained to some extent by the unwillingness of a majority of Voluntary hospitals to admit contagious patients. Unlike voluntary hospitals, there was a higher increase in capacity at proprietary and specialty hospitals (Table 3). Arguably, a proprietary hospital might provide more comfort and privacy for wealthier influenza patients than a public health hospital. The increased capacity of specialty hospitals in the 1910s, which included a large increase in maternity hospital capacity, might be explained by the influenza epidemic, but is probably best explained by the increasing number of births that had moved away from being done privately at home and into hospitals (Stevens).

TABLE 3

\section{COMPARISON OF HOSPITAL TYPES IN CHICAGO IN 1910 AND 1920}

\begin{tabular}{|c|c|c|c|c|c|c|c|}
\hline & & 1910 & & & & 1920 & $\%$ Increase \\
\hline$\underline{\text { Private }}$ & $\underline{\mathbf{N}}$ & $\underline{\text { Tot Beds }}$ & $\underline{\text { Ave Beds }}$ & $\underline{\mathbf{N}}$ & $\underline{\text { Tot Beds }}$ & Ave Beds & in Beds \\
\hline General Proprietary & $\overline{21}$ & 1365 & 65.0 & $\overline{32}$ & 2219 & 69.3 & $62.6 \%$ \\
\hline General Voluntary & 33 & 4432 & 134.3 & 36 & 5680 & 157.8 & 24.8 \\
\hline Specialty & $\underline{14}$ & $\underline{535}$ & $\underline{38.2}$ & $\underline{20}$ & $\underline{1329}$ & $\underline{66.5}$ & $\underline{149.4}$ \\
\hline Total & $\overline{75}$ & $\overline{6232}$ & 83 & $\underline{20}$ & $\overline{8903}$ & 102 & $\overline{45.7 \%}$ \\
\hline \multicolumn{8}{|l|}{ Government } \\
\hline General & 2 & 1450 & 725 & 2 & 3001 & 1500.5 & $107.0 \%$ \\
\hline Public Health & 1 & 125 & 125 & 4 & 1820 & 455 & $1,356.0$ \\
\hline Specialty & $\underline{2}$ & $\underline{476}$ & 238 & $\underline{4}$ & 1168 & 292 & 145.4 \\
\hline Total & 5 & 2051 & 410 & 10 & 5989 & 599 & $192.0 \%$ \\
\hline
\end{tabular}

Note - missing data is taken out of the total sample for calculations

What's especially clear from Table 3 is that the government hospital capacity increased dramatically in the 1910s. That is, the number of public health hospitals in Chicago increased from fourfold (1 to 4$)$ and the capacity of these hospitals increased well over 1000\% (125 to 1820 beds by 1920). Accordingly, existing hospitals had to quickly make room for additional beds, while governments re-purposed buildings with temporary beds and quickly built public health hospitals to handle the surge in patients and for injured troops coming back home from the conclusion of World War 1. ${ }^{4}$ Also, Cook County Hospital doubled its 
bed size from 1350 to 2700 during the period, but the hospital was almost always filled so it might not have been able to do much extra for the influenza epidemic surge. This would have put even more pressure on quickly making public health beds available in the fall of 1918.

\section{The Response of Voluntary Hospitals During the 1918 Influenza Epidemic}

The influenza epidemic's sudden appearance in the fall of 1918 was anything but a normal time. The epidemic put a severe strain on the capacity of all hospitals. When looking at the whole Chicago hospital database, it appears that Voluntary hospitals, due to their non-contagious patient policy, might not have done as much as other hospital types. However, a closer look at individual Voluntary hospitals provides a different story.

Community general hospitals, for example, took in many more charitable patients during the Epidemic. Grant Hospital, which had just changed its name from German Hospital due to World War 1, increased their percentage of free days to almost $30 \%$ in 1918 . This compares with $24 \%$ in 1914 and $13 \%$ in 1909 . At Englewood Hospital, the percent of charity patients increased to over 15\% in 1919 compared to less than $10 \%$ in 1912. In Englewood's case, such an increase in charitable costs was especially difficult since the hospital had no endowment money from which to cover the costs of charitable care.

Catholic hospitals, in general, appear to have provided lower amounts of free care than other religiousbased hospitals in Chicago. They preferred that patients provide at least a minimal payment than no payment at all. For example, in St. Elizabeth's annual report of 1915 the following was written: "Although the hospital is on a firm financial basis, still it remains true that moderate charges, which are made to patients who can pay, are not sufficient to offset current expenses." Yet, during the Influenza Epidemic, Catholic Hospitals responded with heroics.

Despite increasing the size of their outpatient capacity, St. Elizabeth's Hospital had trouble meeting patient demand: "It can readily be seen by the casual observer that the amount of space supplied by the present building is not sufficient to care for the ever increasing number of patients, who apply for admission. .. at times the institution was taxed to its capacity and compelled to turn patients away (1920 Annual Report St. Elizabeth's Hospital: 8). Such comments illustrate how the hospital did the best that it could at the time.

TABLE 4

CHARITABLE AND OUTPATIENT CARE AT ST. ELIZABETH HOSPITAL, 1910-1930

\begin{tabular}{|c|c|c|c|}
\hline Year & Total Patients & Charity Patients & Outpatient Visits \\
\hline 1910 & 1,796 & $18 \%$ & 1,471 \\
\hline 1913 & 2,496 & 22 & missing \\
\hline 1916 & 3,609 & 11 & missing \\
\hline 1919 & 4,475 & 8 & 2,871 \\
\hline 1922 & 4,213 & 9 & missing \\
\hline 1926 & 4,733 & 5 & missing \\
\hline 1930 & 4,153 & 2 & 4,461 \\
\hline
\end{tabular}

Source: Box 101, Folder 22 - St. Elizabeth Hospital annual reports, Sisters of the Poor Handmaids of Jesus Christ archives, Notre Dame University.

Michael Reese, on the near south side, was the main Jewish hospital in Chicago until Mt. Sinai started up on the southwest side, in 1919. Michael Reese had a strong scientific medicine orientation and was the home to many of Chicago's Jewish doctors. However, both Michael Reese and Mt. Sinai provided very high levels of charitable care, too. The Jewish religion was the first to centralize its charitable foundation work in Chicago, having started United Hebrew Charities in 1906. United Hebrew Charities provided high funding levels to Michael Reese and Mt. Sinai to cover the costs of charitable patients. ${ }^{5}$ Cite.

Protestant Voluntary hospitals in Chicago tended to provide charitable care in larger teaching hospitals like Wesley, St. Luke's and Presbyterian, but in only limited amounts in the smaller community hospitals. At Presbyterian, for example, 69\% of 121,249 patient days in 1917 were free or part-pay, and in 1920, 66\% 
of 134,620 patient days were free or part-pay. A smaller protestant hospital, Lutheran Deaconess Hospital, maintained a steady, but lower percent of charitable days. In $1910,12 \%$ of the 17,838 patient days were charitable. In $1919,14 \%$ of 29,008 patient days were charitable and in $1924,15 \%$ of 26,392 patients days were charitable.

In at least some cases, protestant hospitals' responses to the influenza epidemic was heroic. For example, Passavant Hospital, a medium size hospital on the near north side of Chicago's downtown business district, stated the following in their 1918 annual report: All the physical parts of the hospital were overtaxed...that there should be a deficit - and that, a large one - will be no surprise... all epidemic patients were admitted, irrespective of their ability to pay."

\section{DISCUSSION}

The mid-nineteenth century hospital, a charitable asylum for socially marginal invalids, evolved to become an instrument central to the health care of all social classes by the 1920s. This evolution was not a smooth linear trend, but a contested development between various groups including the government, religions, communities and doctors. What this story shows is that the major function of such institutions was not to project an image to the entire community but to serve quite specific needs within their own communities. Like churches, hospitals were agencies of identification for uprooted immigrants, promoting community cohesion. Beyond allegiance to their particular social communities, hospitals evolved into physician workshops.

A second institutional field for hospitals developed in the early 1900s. It evolved as a result of a burgeoning medical science, which became increasingly efficacious in its results. Patients were seen less as products of their social environment and more so through the fundamental principal of modern diagnosis and treatment. As Vogel writes, the contemporary hospital was a place, which abstracts individuals from their everyday world. Several factors account for a mechanistic and reductionist approach at hospitals, including specificity. That is the identification of diseases with unique causes, courses, and pathologies and narrowed the focus from the organ to the tissue and to the cell. Germ theory likewise shifted the doctor's concern away from the whole person, and sought and found infection by microorganisms the causes of many of mankind's most troubling ailments.

Hospital-based physicians most readily assimilated reductionist medicine. They reshaped the institution to fit their needs, emphasizing scientific medicine in place of the charity that had defined the traditional hospital. The hospital, in turn, provided a fitting setting for the medical style that reduced the patient to physiological and biochemical processes. Other social factors helped make hospitalization an appropriate recourse in illness and accident. An urban and industrial society redefined what the individual did for himself. Physically constricted urban living spaces made traditional home care for illness more difficult. So too did another characteristic of the modern industrial order, the spatial differentiation of work from residence. The familiarity of urban and industrial citizens with divisions of labor and specialized settings for different activities heightened their appreciation of the hospital.

An influenza epidemic suddenly appeared in the Chicago area in September 1918 and quickly surged to a high number of contagious patients. Although there was little effective care that could be provided outside of comfort and isolation, hospitals had to quickly make a difficult choice. Should they turn back to their community foundation or stand aside as medical science institutions for non-contagious patients? As archival data indicate, voluntary hospitals in Chicago chose to manage the surge of patients from their neighborhoods.

In some cases, their efforts were heroic. Physicians and nurses worked extended hours and hospitals did what they could to provide extra beds for the surge of neighbors that came to their doors. As is noted in archives of Passavant Hospital, "all epidemic patients were admitted, irrespective of their ability to pay." Although these hospitals might have seen their admittance of poorer, contagious patients as a short-term issue, there is little evidence of this in the archives. Voluntary hospitals continued to provide communitybased care during the subsequent waves of the influenza epidemic that occurred in 1919 and 1920. Indeed, well beyond the influenza epidemic, there is additional evidence that voluntary hospitals were heroic in 
providing for their communities during the Depression years (31). The active response by Passavant and other voluntary hospitals to the 1918 influenza epidemic served to re-inforce the original community service orientation that led to the quick proliferation of hospitals at the turn of the $20^{\text {th }}$ century. In effect, the epidemic crystallized what it meant to be a voluntary hospital. This identity included the capacity to choose their primary function while maintaining their institutional legitimacy as a community institution.

\section{ENDNOTES}

$1 \quad$ Chicago had a massive influx of people, and especially immigrants, at the turn of the nineteenth century. Chicago was the $4^{\text {th }}$ largest city in the United States in 1880, but by 1890, with a population of 1,099,850 (Chicago had become the second largest city and it was growing quickly. In 1900, Chicago's population size increased to 1,698,575 in 1990 (54.4\% growth in a decade). In 1910, the population size of Chicago continued to increase to 2,185,283 (28.7\% growth in a decade), and in 1920, the population of Chicago was 2,701,705 (a 23.6\% growth in a decade).

2 In 1919, the Illinois Insurance Commission Report of 1919 indicated 860,000 visits to hospital out-patient clinics and dispensaries in Chicago in 1917. More and more workers, unable to afford private physicians but otherwise self-sufficient, turned to low cost dispensaries for health care. Also, the Commission was surprised to discover that four out of five families had protected one or more members with some form of life insurance or funeral benefit. Bohemians and Poles far surpassed the average of 82 percent, with 89 percent of their families holding life insurance; Jews and Italians, with 64 and 58 percent, respectively, held less than the average, although still a substantial number, of policies (223). Within an ethnic group, individuals' life insurance holdings depended on their economic prosperity. The larger number of families without insurance and the smallest policies were typically those with the lowest incomes and, unfortunately, the greatest need.

3 For example, German Hospital (aka as Grant Hospital) of Chicago screened patients for worthiness in their Social Services Department. In their 1928 annual report (page 9), the hospital reported: "During the last fifteen years a total of 134,085 days of absolutely free care was rendered to patients who were found worthy."

4 Note that the War ended during the epidemic (November 11, 1918) and that more American troops died from the influenza epidemic $(58,000)$ than died from battling in the war $(53,000)$.

5 A conversation by the author with Michael Tarnoff and Dr.Peter Friedman of the Jewish Federation of Chicago, February 6, 1991. The other primary religious groups in Chicago, the Protestants and the Catholics, had relatively little centralized foundation support at the time. The Chicago Archdiocese was centralized in the 1920s under Archbishop Mundelein. However, the centralization of Catholic parishes into a diocese in Chicago in the 1920s did not affect the Catholic hospitals, which were left financially independent in the care of the particular religious orders.

\section{REFERENCES}

American Hospital Association. (1920-90). Annual Survey of Hospitals. Chicago: American Hospital Association.

Bonner, T. (1957). Medicine in Chicago, 1850-1950. Madison, WI: The American History Research Center.

Bowman, J. (1987). Good Medicine: The First 150 Years of Rush-Presbyterian-St. Luke's Medical

Center. Chicago: Chicago Review Press.

Chicago Medical Society. (1908-13). Bulletin of the Chicago Medical Society.

Chicago Medical Society. (1922). History of Medicine and Surgery: Physicians and Surgeons in Chicago. Chicago: Biographical Publishing Co.

Cohen, L.H. (1990). Making a New Deal. New York: Cambridge University Press.

Cook County Commissioners. (1926-27). Proceedings of the Board of Commissioners. Chicago: Cook County.

Davis, M.M., \& Warner, A.R. (1918). Dispensaries. Their Management and Development. New York: Harper \& Brothers.

Davis, M.M. (1921). Immigrant Health and the Community. New York: Harper \& Brothers.

Davis, M.M. (1927). Clinics, Hospitals, and Health Clinics. New York: Harper and Brothers. 
DiMaggio, P.J., \& Powell, W.W. (1991). Introduction. In W. Powell \& P. DiMaggio (Eds.), The New Institutionalism in Organizational Analysis (pp. 1-40). Chicago: University of Chicago Press.

Fishbein, M. (1969). Morris Fishbein, MD: An Autobiography. New York: Doubleday.

Friedland, R., \& Alford, R. (1990). Bringing Society Back In: Symbols, Practices, and Institutional Contradictions. In W. Powell \& P. DiMaggio (Eds.), The New Institutionalism in Organizational Analysis (pp. 232-66). Chicago: University of Chicago Press.

Gifford, B.D. (1993). Community and Organizational Change: The Development of Chicago's General Care Hospitals from 1910 to 1960. PhD dissertation (sociology). U. of Chicago.

Henderson, C.R. (1896, February). How to Care for the Poor without Creating Pauperism. Charities Review, 5, 182-87.

Houghteling, L. (1927). The Income and Standard of Living of Unskilled Laborers in Chicago. Chicago: University of Chicago Press.

Hunter, R. (1904). Poverty. (New York: MacMillan; reprint, New York: Harper Torchbook, 1965).

Klarman, H.A. (1963). Hospital Care in New York City: The Roles of Voluntary and Municipal Hospitals. New York: Columbia University Press.

Lyon, H.F. (1947). The History of Public Health Nursing in Chicago, 1883-1920. MA Thesis, University of Chicago.

Numbers, R. (1978). Almost Persuaded. Baltimore: Johns Hopkins University Press.

Patterson, K.D., \& Pyle, G.F. (1991, Spring). The Geography and Mortality of the 1918 Influenza Pandemic. Bulletin of the History of Medicine, 65(1), 4-22.

Report of the Health Insurance Commission of the State of Illinois. (1919). Springfield: State of Illinois.

Report of the Judicial Council. (1913). Journal of the American Medical Association, 60, 1988-96.

Robertson, J.D. (1919). Report and Handbook of the Department of Health of the City of Chicago for the Years 1911 to 1918 Inclusive. City of Chicago.

Rosenberg, C.E. (1987). The Care of Strangers: Rise of the American Hospital System. New York: Basic Books.

Rosenberg, C.E. (1989). Community and Communities: The Evolution of the American Hospital. In D.E. Long \& J.G. Ithaca (Eds.), The American General Hospital: Communities and Social Contexts (pp. 3-17). NY: Cornell University Press.

Rosner, D. (1982). Health Care for the "Truly Needy": Nineteenth-Century Origins of the Concept. Millbank Memorial Fund Quarterly, 60(3), 355-85.

Rosner, D. (1988). Heterogeneity and Uniformity: Historical Perspectives on the Voluntary Hospital. In J.D. Seay \& B.C. Vladeck (Eds.), In Sickness and in Health: The Mission of the Voluntary Health Care Institutions (pp. 87-126). New York: McGraw-Hill.

Rosner, D. (1982). A Once Charitable Enterprise. New York: Cambridge University Press.

Ruth, D.E. (1990, Fall \& 1991, Winter). Don't Shake--Salute! Chicago History, XIX(3-4), 4-23.

Serums and Vaccines in Influenza. (1918, October 26). Journal of the American Medical Association, p.1408.

Starr, P. (1982). The Social Transformation of American Medicine. New York: Basic Books.

Stevens, R. (1989). In Sickness and in Wealth: American Hospitals in the Twentieth Century. New York: Basic Books.

Stevens, R. (1984, Fall, Winter). Sweet Charity: State Aid to Hospitals in Pennsylvania, 1870-1910. Bulletin of the History of Medicine, 58, 287-314 \& 474-495.

Toner, J.M. (1873). Statistics of Regular Medical Associations and Hospitals of the United States. Journal of the American Medical Association, 24, 314.

U.S. Bureau of the Census. (1904 \& 1910). Survey of Benevolent Institutions. Washington D.C.: Government Printing Office. 